SOME ACCOUNT OF LIEUT.-COLONEL WILLIAM MERCER, AUTHOR OF "ANGLIA SPECULUM; OR, ENGLAND'S LOOKING-GLASSE." LoNDon, 1646. By DAVID LAING, Esq., V.P.S.A., Scot.

At an early period, more especially during the first quarter of the seventeenth century, many of our countrymen went abroad, to push their fortune at the point of the sword. Some of these, like Sir Alexander Leslie, afterwards Earl of Leven, Sir Patrick Ruthven, Lieut.-General William Baillie, and David Leslie, Lord Newark, returned to Scotland, to distinguish themselves in the Civil Wars into which the misguided policy of Charles the First involved these kingdoms; but there were others, Hamiltons, Hepburns, Ramsays, Douglasses, and Setons, who, after serving "the great Lion of the North," remained abroad, and whose descendants, in various parts of the North of Europe, more especially in Sweden, have continued to flourish. Colonel William Mercer, of whose life and writings I purpose to give some account, followed, at an early period of life, a similar course; but he can scarcely be reckoned among those "mercenary swordsmen," like the inimitable Dugald Dalgetty, or his prototype Sir James Turner, who were by no means scrupulous as to which party they served.

The family of MerorR in Scotland is one of considerable antiquity, as their names occur in the public records from the thirteenth century. The chief of the name was Mercer of Aldie, or, ns commonly pronounced, Awdie, in Perthshire. From this stem there branched off various families -the Mercers of Clevage, Inverpeffray, Meiklour, Melginche, Salinshaw, and others; but having no particular faculty for pursuing Genealogical inquiries, my design is limited to the individual of the name, whose 
verses, often enough but mere doggerel, furnish us, nevertheless, with some curious gossiping particulars of his own history.

William Mercer was born, probably, in the parish of Methlik, Aberdeenshire, about the year 1606. His father, Mr John Mercer, was educated for the church, in King's College, Aberdeen, and became minister of Methlik, towards the close of the sixteenth century. In October 1618 he was translated, upon a presentation by King's College, to the church of Slains; and he survived till 1637 or 1638. At the age of fifteen, his son William, having no disposition for learned pursuits, fled from school; and, with a restless spirit, embracing the military profession, he passed abroad, forming this resolution, in the words of Sir David Lyndsay,

For I am young, and thinkis to pas till France, And tak wages, amang the men of weir, And win my living with my șwerd and speir. ${ }^{1}$

At a later period of life, in an address to Charles the Second, in reference to his deficiency in scholastic learning, Mercer says :-

When of my age, I was but twelve and three, I fled from school, where few such followed me, And serv'd an Emperor, and in much ado I serv'd in Denmark, and Gustavus too:

Serv'd all the three, but each of them one year, Took never pay, not sinning, I may swear: So that it seem'd amongst so many men, I toss'd a pike more than I spoil'd a pen.

In reference to his early military career, he elsewhere says :2

Before my sight four times six years had seen, Throughout six kingdoms had my body been, Bore Arms in each ; where, seeing all that's there, I view'd one vice, much made of every where, Ingratitude.

Finding such employment so unprofitable, he bethought himself of such an unsettled course of life, and returned to his friends in Scotland. This

1 Satyre of the Three Estates, in Lyndsay's Works, vol. ii. p. 110.

2 Mercer's News from Parnassus, 1682, p. 67. 
must have been before 1630, as that year, on the 28th of June, a letter of presentation was granted by Charles the First in favour of "William Mercer, sone lawfull to Mr Johnne Mercer, minister at Slaynes, to the personage and vicarage of the teyndis, \&c., of the kirk and parochine of Glenholme," \&c. This was one of the prebends attached to the Chapel Royal of Stirling. Whether this presentation was confirmed is uncertain. Probably not: it was at least not requisite for the presentee to hold any orders in the Church, the only qualification, if any such were required, was a knowledge of music. Various instances might be quoted of similar benefices having been conferred for a period of seven years, for the purpose of enabling a youth to pursue his academical course. ${ }^{1}$

In my early days of collecting books by Scottish authors, I chanced to pick up at a sale a little dirty volume, in verse, without a title page, but having the author's initials, W. M. One portion of it, called, "Edinburgh's Alphabet," is accompanied with a series of anagrams, acrostics, and sonnets, upon each of the names, some of them not the most classical, setting forth the merits of the Lord Provost, Bailies, and Deacons of Edinburgh-a somewhat hopeless task at any time-for the years 1631-1632. That the author who uses the phrase, "I vowe heare by a Soldier's hand," was William Mercer, is beyond all question, if this juvenile work be compared with his later effusions. At the time, however, being unacquainted with such writings, on applying to my old friend, the autihior of "Calcdonia," to ascertain the anthor's name, and having suggested whether, from the initials W. M., it might not be an early production of Sir William Mure of Rowallance, his answer was, the book was quite unknown to him (nor has any other copy since been discovered); but he could not imagine that "the Knight of Rowallane would have condescended to flatter the Town's Magistrates most unmercifully for a shilling."

From an incidental allusion in his Anglice Speculum, we learn that Mercer's first military employment was in Ireland: the time is not

1 By two Acts, 12th and 158th in the 1st and 12th Parliaments of James the Sixth, patrons of Provostries, Prebendaries, and Alterages holding of the Crown by infeftment, were allowed to present the same to bursars in Colleges, at their pleasure, notwithstanding any foundation or confirmation to the contrary. 
344

specified, but in his intended Chronicle of events of which he was eyewitness, he dates this about 1638. His words are :-
I lost my living in that Irish land, Where, by commission, I had first command;
My father's heir was therein put to sword, His wife was also cruelly devour'd, His goods destroyed, his children sent abroad To beg; and I was scourged with this rod.

This mention of his father's heir refers to his elder brother, Mr Robert Mercer, Master of the Grammar School at Ellon, in Aberdeenshire; who demitted his office in the year 1628, and having settled in Ireland, he and his family became victims of the great Irish Rebellion, as a martyr to the Protestant cause.

During the Civil Wars, Capt. Mercer, in opposition to the sentiments of some of his relations, took the part of the Covenanters, or, as he afterwards found it convenient to call it, the State, and had interest enough to obtain from Robert, Earl of Essex; General of the Parliamentary forces, a commission as captain of horse.

In the early part of the year 1646, Captain William Mercer published a volume, well known to collectors of English poetry, under the following title, "Anglice Speculum: or, Enaland's Lookina Grasse, devided into two parts; the first part containing a brief description of these unnatural wars in England, with some particular persons, fomentors thereof, discovered ; the vast expenses, and the glory of the famous city of London, in maintaining the Protestant religion, and their privileges displayed. The second part, consisting of several speeches, anagrams, epigrams, acrosticks, and sonnets, \&c., by C. W. Mercer. London, printed by T. Paine, \&c., 1646," 4to. ${ }^{1}$ It is inscribed in terms of attachment to his patron the General, and has the Earl's portrait prefixed. The volume, as the title states, consists of two parts: in the first he presents, as in a looking-glass, an epitome of England's troubles; and, in celebrating the first and great encounter of the contending parties at Edge Hill, 23d October 1642 , he states that, so far as the charge he had permitted him,

I In some eopies there is the simple title, "Anglia Speculum: or, Englands Looking Glasse. Devided into two parts. By C. W. Mercer. London : Printed by Tho. Paine, Mdcxlvr." 
he was an eye-witness of this memorable conflict. In the second part, is a series of detached pieces, speeches, anagrams, epigrams, acrostics, and sonnets, chiefly interesting for the names of the persons to whom they were addressed.

Thus we have, besides the Lords and Commons assembled in Parliament, the Scottish Commissioners to the English Parliament, many of the nobility and persons of rank; and, in particular, Richard, Earl of Warwick, the Right Worshipful Sir Henry Mervyn, his father-in-law, the truly honourable colonel, Colonel Audeley Mervin, his brother-in-law, his brother, Captain John Mercer, and " the famons poet," Captain George Withers. The concluding poem, in the form of a petition to the Lords and Commons, and the Lord Mayor and Common Council of London, presents a sad picture of the distress to which he was reduced by the arrears of pay due to him, extending in amount to L.900; one-half or a third part of which he earnestly solicits for the relief of his urgent necessities. A portion of this petition may be quoted.

He says,-

But now your true Petitioner indeed

Is so confounded, as you here may read, That I am almost wearied of my life, Tir'd and tormented with this cruel strife, The cries of children and an angrie woman, Two heavy anchors, when they're tyde unto men; 'They cry for money, bread, and beer, anà beefe, But they may eat their fingers for reliefe. * * * * * *

When I'me abroad, I stand and stare to skan, Lest I on sudden meet a Marshall's man, This is most grievous, and a great disgrace, A Souldier dare not look men in the face : And I'me already run so in the score, To tell the truth, they will not trust me more. And now the Printer, and the Stationer, Threatens to prison your Petitioner.

It appears that this sad state of affairs had existed for a considerable period. On the 20th of March 1642-3, a petition of . . . Mercer was read, and remitted by the House of Commons to the Committee for Exa- 
minations. ${ }^{1}$ On the 20th of December following, strict orders were given by Parliament regarding moneys brought into Chancery of malignants or . delinquents, that some part of it might be employed to satisfy the English and Scots Reformado Officers ; and on the same day, the House of Commons "Ordered, That the petition of Wilutam Mercer, Alexander Nearne, David Robinson, Patrick Forbes, and others, this day presented to the House, be referred to the Committee for the Reformado Officers, and by them considered of, and reported, before any monies be paid over to the Scotts Reformado Officers." 2 According to his own statements, Captain Mercer was referred from one Committee to another, and from Parliament to the Mayor and Aldermen of London, but all the time was left in great destitution. In the Journals of the House of Lords, Ist May 1646, 22 Car., we find: "Capt MIercer's petition for Arrears," as follows :-

"Upon reading the Petition of Capt. Ww Mercer, desiring some part of his Arrears mäy be paid him, for the Service of the State: It is Ordered, to be recommended to the House of Commons." ${ }^{3}$ The result of such recommendations is not stated. But his great patron having died a few months after the publication of his " England's Looking Glasse," Mercer bewailed his loss in "AN Elugax upon the Death of the Right Hon"le, most Noble, worthily Renownend, and truly valiant Lord, Robert Earle of Essex and Ewe, \&c., His Excellency, late Lord General of all the Forces raised by the Parliament of England in defence of the Protestant Religion. Who departed the 14th of September 1646." A copy of this, "London printed by I. C. 1646," in the form of a broadside, is preserved among the King's Tracts in the British Museum. In like manner, he had previously bemoaned the death of his father-in-law, under this title:- "AN ELEGre in memorie and at the interring of the bodie of the most famous and truly noble Knight, Sir Henry Mervyn, paterne of all true valour, worth, and arts, who departed this life the 30 of May, and lyes interred at Westminster, Anno Do. 1646. London printed by James Coe, 1646," a folio broadside. This I have not seen; but it occurred in a valuable collection of ballads, poetical pieces, \&c., at Bindley's sale, 1820, No. 1125. (James Chalmers's MSS., p. 226.)

1 Journals, vol. iii. p. $10 . \quad 2$ Ib., vol. iii. p. $346 . \quad$ Ib., vol, viii. p. 291. 
After the death of King Charles the First, the disturbed state of Ireland required the English Commonwealth to take some decided measures to subdue the Irish rebels. In March 1649, Cromwell was elected to the Lieutenancy of Ireland, although it was not until August that he himself set out thither. But while he was engaged in collecting an army of 12,000 men in the west of England, he previously sent a reinforcement of 4000 horse and foot; and measures were then taken to pay such arrears as were due. In this number Captain Mercer's troop of horse formed a part. The following notice occurs in the newspaper called the "Perfect Diurnal," April 16-23 :-

Friday, April 20th 1649.

"This day (according to appointment) the General Council of the Army met at Whitehall, about casting of lots what Regiments should go for the service of Ireland, where, after a solemn seeking of God by prayer, they cast lots what Regiments of the old army should be designed for that service, $14 \mathrm{Reg}^{\text {ts }}$ of horse and 14 of foot of the Established forces came to the lot; and it being resolved that four Regts of Horse and four of foot should go upon that service, 10 blanks, and four papers with Ireland written upon them were put in a hat, and being so shuffled together, were drawn out by a child, who gave to an officer of each Regt in the lot, the lot of that Regt,--so that it was done in so im- partial and inoffensive a way, as no Regt can take any just exception. The Regts whose lot it fell to go were "W- Here the different horse and

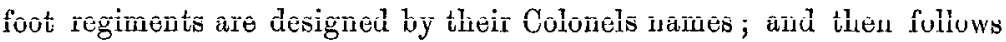
the troops of dragoons, also designed by the names of their Captains; and among these appears, "Captain Mercer's troop." It is added, "The Officers of each Regiment which were allotted expressed much cheerfulness at the decision."

That this was Captain William Mercer is most probable. About the same time he was raised to the rank of Lieut.-Colonel, yet singular enough, in the spring of 1650 , we find him in Scotland, still in reduced circumstances. The notice is interesting, as it serves so clearly to fix his parentage. It occurs in the unpublished Minutes of the Commission of the General Assembly:-

"Edinburgh, 23 May 1650.-The Commission of the Generall Assembly considering the necessitous condition of Lieutenant Colonell William 
Merser, sone to umquhill Mr Johne Merser, minister at Slaines, doe referre him to the charitable supplie of the Presbyterie of Edinburgh." The Minutes of the Presbytery of Edinburgh for this period are not preserved, so it cannot be said whether any collection in his behalf was made.

In the following year, honourable mention is made of a Major Mercer among Cromwell's troops at the battle of Worcester. ${ }^{1}$ I can only con. jecture that this may have been the colonel's brother, the Captain John Mercer of 1646. Another Lieut.-Colonel James Mercer casts up among the Royalists in the North of Scotland, under Lieut.-General Middleton, in the year 1654. In a letter from Inverness, 21st June 1654, Colonel Morgan relates, that a party of 600 horse and foot, under the command of Drummond, Erwiñ, Mercer, and Selkink, was routed and pursued for 10 miles $;^{2}$ and an intercepted letter to Middleton from this Lieut.Colonel James Mercer, on the 13th of November that year, refers to the hopeless condition to which their small party was reduced. ${ }^{3}$

For several years no further notice of the Reformado officer or the rhyming Colonel has been discovered. After the Restoration of Charles the Second, he, like many others, gave expression to unbounded loyalty, having visited the King at Whitehall, most likely soliciting a pension. Upon the occasion of John Lord Roberts, Baron of Truro, being appointed Governor of Ireland, September 18, 1669, our "constant lover of the muses," Lieut.-Colonel William Mercer, printed "A Wercom in a Poem, to His Excellency, \&c., at his Royal entry into the Castle of Dublin;" or, as a second title-page has it, "Terbum Sapienti, or Mercer's Muse making Melody, in a Welcom to His Excellency John Lord Roberts, Baron of Truro, \&c. Dublin, printed by Josiah Windsor, 166[9]. 4to, 16 leaves. The under part of the last figure, in both title-pages, being cut off by the binder, looks like 1660, in place of 1669 . There can be no doubt regarding the date, as John Lord Roberts was appointed Lord Lieutenant of Ireland, September 18,1669, and was succeeded, May 10, 1670, or within eight months, by John Lord Berkeley of Stratton. The copy I have is not quite perfect; but $I$ have searched in vain, in Dublin and elsewhere, to see another copy to supply the apparent defect of the last leaf.

1 See Extract in volume Cromwelliana, pp. 111, 112. Lond. 1810, folio.

2 Thurlow's State Papers, vol. ii. p. 388.

3 Ib. p. 725. 
Another unique production, preserved in the Grenville Collection in the British Museum, is entitled "The Moderate Caualier; or the Soldier's Description of Ireland and of the Country Disease, with Receipts for the same.

"From Glocester siege till arms lay'd downe

In Trewroe fields, I for the Crowne, Under St George march'd up and down;

And then, Sir,

For Ireland came, and had my share

Of blows, not lands, gain'd in that warre;

But God defend me from such fare

Again, Sir.

"A book fit for all Protestant houses in Treland. Printed anso dom. mDctxxv." 4to, A to I in 4's (18 leaves not numbered, or pp. 36). This is a rambling production, throwing no light on the author's history beyond the lines on the title-page. I have no doubt it was by Mercer, although his name is not given; and $\mathrm{Mr}$ Grenville must have had some authority for so asserting it,-most likely some note in the volume before it was rebound.

On the back of the title are the following lines, addressed "To the Protestant Nobility, Gentry, and Soldiers of Ireland, but more especially to the Worshipfull the Mayor, Aldermen, Sheriffs, Citizens, and Inhabitants of the City of Cork."

A Soldier for the KING (great Sirs) to you

Humbly presents this little book to viewe,

Which speaks of storyes old and not of newes,

Things to most of you known : may be of use

In after ages when we're dead and gone,

And 'mongst all Protestants worth thinking on.

He stiles his book The Mod'rate Cavalier,

Which whoso reads will find him so appear;

He's no Incendiarie, to blow the fire

Of discussion 'mongst factions, or desire

Warres, being content with his low estate,

But sorry that (too true) he can relate

No more of good encouragement from friends

To the poor soldiers who deserved amends

For their past Service were to be forgott,

Whilst in Ireland's an Englishman or Scott. 
Be pleas'd, therefore (dear Sir), to patronize

The Soldier's worke, that to his Enemies

He be no made contemptible, whose drift

For a poor living's only to make shift,

Which being granted, the soldiers I say

For you and yours Eternally shall pray.

Followed by thirty-six lines. "The author upon his intent to have presented three dozen of these books to the Major of Corke and his guests and his Friends when he first comes into his Office," concluding,

It only rests that I now for my paines

No loser be; if that I get no gaines,

'Then, what you please, to the Poet or Printer,

"Twill be an help to keep a Fire in winter.

The volume ends with a Dialogue betwixt the Soldier author of the book and an Echo.

I now come to an incident in Colonel Mercer's life, which led him, in 1672 , to revisit his native country. This was a proposal for a matrimonial alliance betwixt his eldest son and the heretrix of the barony of Aldie. He himself was great in the marrying line ; he says-

For in my tyme I maried four fyne wives,

For by such matches many bad men thrives;

Two maids between two widows, first and last;

The first three fail'd, but now the fourth holds fast:

A Murray, Mervyn, Connway, and a Duff;

My Lady smyles, and sayes these wer enuffe!

The lady here mentioned was Dame Jean Stewart, Lady Aldie. Sir James Mercer of Aldie, knight baronet, and one of his Majesty's ordinary gentlemen ushers, died in 1671. A few years previously, he executed a deed of tailzie and provision, by which his estates, without division, failing heirs-male, were settled on his eldest daughter, the said heirsfemale successive in all times thereafter being obliged to marry a gentleman of the surname of Mercer, or one of another surname who should take that of Mercer, they and their heirs always using the surname and arms of Mercer. This is stated at full length in the "Act of ratification in favour of Mistress Grissell Mercer, Ladie Aldie, of the lands and barony of Meiklour," 6th September 1681, printed in the Acts

I Acts Parl. Seotl., vol. viii. p. 330. 
of the Parliament of Charles the Second. It further appears, from the reported case of an action in the Court of Session, Lieut.-Colonel William Mercer against the widow Lady Aldie, that the suitor would be required not only to assume the name of Mercer, but be of sufficient means to pay off the debts and portions of the family; and as it was alleged there was no one of the name in Scotland of sufficient means to perform this condition, the dowager sent a natural son of her late husband to Ireland to invite the colonel, being near of kin, to contract an alliance with his eldest son. He accepted the invitation, was hospitably received, and he returned to Dublin to raise the sum of two thousand pounds sterling, and bring over his son to conclude the match. The money was accordingly provided by the youth's maternal relations, and they both came to Scotland full of expectation; but lo, from some unexplained cause, the dowager's plans had undergone a change, and she could not so much as even allow the young expectant to see Mrs Grizzel. What wonder, therefore, that the old colonel should feel aggrieved at such conduct, and resolve he should not

" be abused,

Invited, treated, frown'd on, and confused;

(Nor that matters should) be brought to that pass,

To come to Scotland, and turne back ane ass."

He accordingly raised an action of damages, for breach of a verbal treaty of marriage, and expenses, before the Court of Session. The case is reporieu in Siair's and Grossford's Decisions. i Turing this litigation, and in the view, no doubt, of inclining the judges to a favourable decision, he prepared, as a New Year's gift to them, a series of encomiums, which he says-

Shall scrve for lasting monuments of your fame.

His epistle dedicatory begins-

Most NoBLE LoRds,

Seven kingdoms I have compast in my days, And now am come to write your worthy praise;

I have escaped prison, plunder, warr, And did partake of all the ills that are.

1 See also Morison's Dictionary of Decisions, pp. 3150-3153. 
This performance is entitled "A Compendoods Comparison of the Lives and Lawes of the Senators of Rome, with the Lives and Lawes of the Senators of the Colledge of Justice, Edingburgh, in Familiar Lynes and Poems. By a Servant to Mars and a Lover of the Muses, Lie ${ }^{\text {rt.-Coll11. }}$ William Mercer. Edinburgh, 1673." MS., 4to, pp. 34, Advocates Library.

On the back of the title-page are the following lines, called "A Sonnet."

Strange Revolutions in those parts appear,

Now one as strange as true is happened here;

Lift leafe by leafe untill you scan a score, And you shall see things never seen before:

Rome's Worthys vertues, with our Worthys weigh'd,

But quite borne downe cannot be now deny'd ;

Now Plutarch's Lyves ly under cloud ecclipt,

All now come calling Mercer's Mantuscript,

A thing so sar'd, so many thousand years

Supprest ; so now by Scotland's worthy Peers,

This is the thing a wonder may be thought,

As I may swear this book is dearly bought;

And this same Sonnet proving as I praise,

The saddest song $I$ sung in all my dayes.

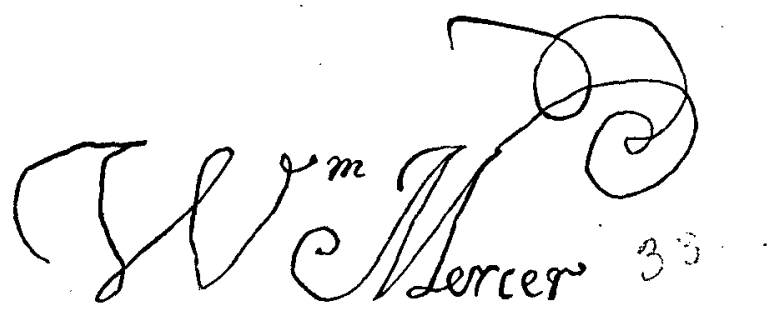

But notwithstanding such a modest assertion, he throws the most distinguished Greeks, as well as Romans, into the scales. Thus, his first worthy, John Maitland, Duke of Lauderdale, the Lord High Commissioner, he compares to Themistocles ; and "Heroic Rothes," Lord Chancellor, to Pericles ! His other comparisons are not a whit more appropriate. For instance, Earl of Athole, to Alcibiades ; Earl of Tweeddale, to Marcellus; Alexander Earl of Kincardine, to Alexander the Great; 
President Stair, to Sertorius ; Primroso, Clerk-Register, to Phocion; Nisbet, Lord Advocate, to Aristides; Lockhart, Justice-Clerk, again to Pericles; and so on with the other eleven judges; on each of whose names he has an anagram, with so many lines, and a concluding couplet for the Comparison.

Towards the close of the MS. is the "Penman's Appologie," in which Mercer urges his son's claims to secure Grissel, and implores their Lordships' favour in the lines already quoted as to his own domestic fortunes; and be gives the following picture of Highland hospitality in the person of Sir Thomas Stewart of Gairntully :-

"He feasted me a month at Murthly House, * No man in Fyfe nor Angus, being able,
Doth keip so fair and full a furnisht table;
I say by sight, for I with him have been,
And in this land the lyke have seldom seen,
So well-drest dishes, wynes too much, and more,
Nor lock nor key, there stands an open dore."

The recollection of such cheer leads him honestly to avow, that while his son, like a young gallant, had declared he was willing to take Mrs Grissel " had she neir a groat," he for himself was equally willing-

$$
\text { "were it for. no more }
$$

But to be dwelling nere Sir Thomas' dore:

Young fools affirme it is for love they woow,

My courting is for cake and pudding now :

With Grantully and with Lethanty, I allege,

Best courting now for men that's of our age.

But all this time I talk like to an ass,

And tells my mind, Post Vinum Veritas."

It was only after a lapse of nearly three years that the Lords of Session gave a decision on the 14th December 1675, to this effect, that as there was no marriage-contract or written agreement, a mother's verbal assurance was not binding; but as it was not denied the pursuer had been invited to come to this country for the proposed alliance, he was entitled to expenses. It so happened, in the course of events, Mrs Grissel remained unmarried; a younger sister, who married Sir Laurence Mercer, VOT. III. PART III. 
inheriting the property; but we may hope the young lad found less diffculty in finding a suitable match among the ladies of Ireland.

Another case is reported as decided on 15th December 1681, ${ }^{1}$ when William Mercer pursued unsuccessfully for the recovery of a bond of 2300 merks, bearing annual-rent, granted by Sir James Mercer of Aldie, in 1643, to this William Mercer of Clevage's grandfather, but which, it was alleged, must have long since been cancelled. On the erroneous supposition that both actions had been raised by the same person, much pains were taken to trace the Colonel's descent as representative of the Mercers of Clevage; but it is quite evident that his nearness of kin to the Aldie family must be traced to a younger son of that house. (See table, p. 357.)

After the termination of his famous lawsuit, we may conchude that Colonel Mercer and "the lad" returned to his family in Ireland; but I have met with no further particulars regarding his history, after making a fruitless search in Dublin to ascertain whether he died in that city, or if his will was on record. ${ }^{2}$ He had visited London, however, in 1682, the date of a book which he published under this title- "News mom ParNASSES, in the Abstracts and Contents of three Crown'd Chronicles, relating to the three Kingdoms of England, Scotland, and Treland. In a Poem, divided into two parts: First, To the King; secondly, To the Subjects of the said Three Kingdoms. Dedicated to his Majesty. By a Servant to Mars, and a Lover of the Muses, William Mercer. London : printed by M. W., for the Author, 1682." 8vo, pp. 94.

It begins, as usual, with Anagrams; but the drift of the work was, in a cheap form, to 'call attention to his "big book," compared to Noah's Ark, which had occupied him for twenty years, "being a rhyming Chronicle of the passages, parties, and persecutions, within the three Kingdoms, from 1638, about which time the Troubles arose in the said kingdoms. . . . With my own personal presence, being an eye-witness thereunto, having had employment, in good capacity, from the very first in England, a native of Scotland, a long liver in Ireland, \&c."

1 Morison's Dictionary of Decisions, pages 12708-12712.

2 A William Mercer died in Dublin in the ycar 1695; but his will furnishes no indications of any relationship. 
In his dedication to Charles the Second, he says,

"To end the Ark, appoint a pension, Should it be small, nine hundred sheets now nigh

To put to press, whenever the Author dye :

But I am pleas'd this instant hour to print

The Piece . . . ."

Towards the end of the volume Mercer compares himself to Virgilius Maro, in what he calls Sonnets; thus-

"I, The Author, on Mrself, and to Mrself, in Sonnets.

Because that no man praises me,

I'll praise my self, now you shall see

Two ways; one is, by Comparing;

Th' other Patience, being so sparing;

And though men's praises first are penn'd,

I put my own praise at the end."

" FIRST SONNET.

I, MERCER, though my skill be scarce, Compare with Maro making verse;

Tell too, my tattling is not Treason, Though it be not good Rhime nor Reason :

And says my News now from Parnass, Do let few faulty persons pass."

"Second Sonnet.

Comparisons to bring abuse are bent; But these ensuing seem to give consent :

For when wise Maro penn'd Mecænas praise, He took not pains, as Mercer making these, Then Mercer's merits may with Maro's Muse Compare in this, few men may that refuse : Maro prais'd one, and for his praise was paid; Mercer to Millions praises hath display'd, In rich Encomiums, and hath undergone (Like Mars and Maro, both combin'd in one.) For to defend what he hath penn'd by word, Affirming he will sign it with a Sword.

So Mercer may to purchase modest praise, Compare with Maro in composing these.

Then for which praise to make his pen repine

Were not praiseworthy, saith Saint Augustine." 
The volume ends on page 94 , with

"A Farewel Sonnet.

Twice twenty Terms, and almost every hour,

I tyr'd my pen, employing of my power

To prove these Poems; then in all I say

No Learning lyes, though on the points I play.

The Latin I do grant, by guess I got,

Cannot well tell if it be true or not,

I bruis'd my brains; dare not deny indeed,

But in my haste, I have broke Priscian's head.

I play'd my part, can now not labour longer,

And am afraid, some hang themselves in anger.

This Pamphlet I of purpose publish cheaper,

My big Book's nigh nine hundred sheets of Paper.

. In short, beside so many motions made,

This Sonnet says now, No more shall be said."

And elsewhere he adds,

"But to my Prince at present I appeal, And humbly hereto set my hand and seal."

William Mercer.

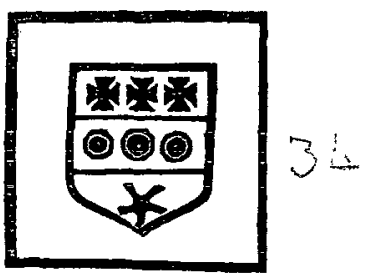

Colonel Meroer at this time must have been far advanced in years, and he probably neither long survived the appearance of this pamphlet, in 1682, nor received any pension. His "big Book," which he so frequently calls " his.Ark" - and which he seems to have contemplated with admiration on account of its bulk (only think, nine hundred sheets of $\because$ paperl) was, unfortunately, not sufficiently buoyant to be an Ark of safety for his protracted labours of twenty years: but we may console ourselves with the certainty that this was not the greatest loss which the literary World has sustained. 


\section{ANTIQUARIES OF SCOTLAND.}
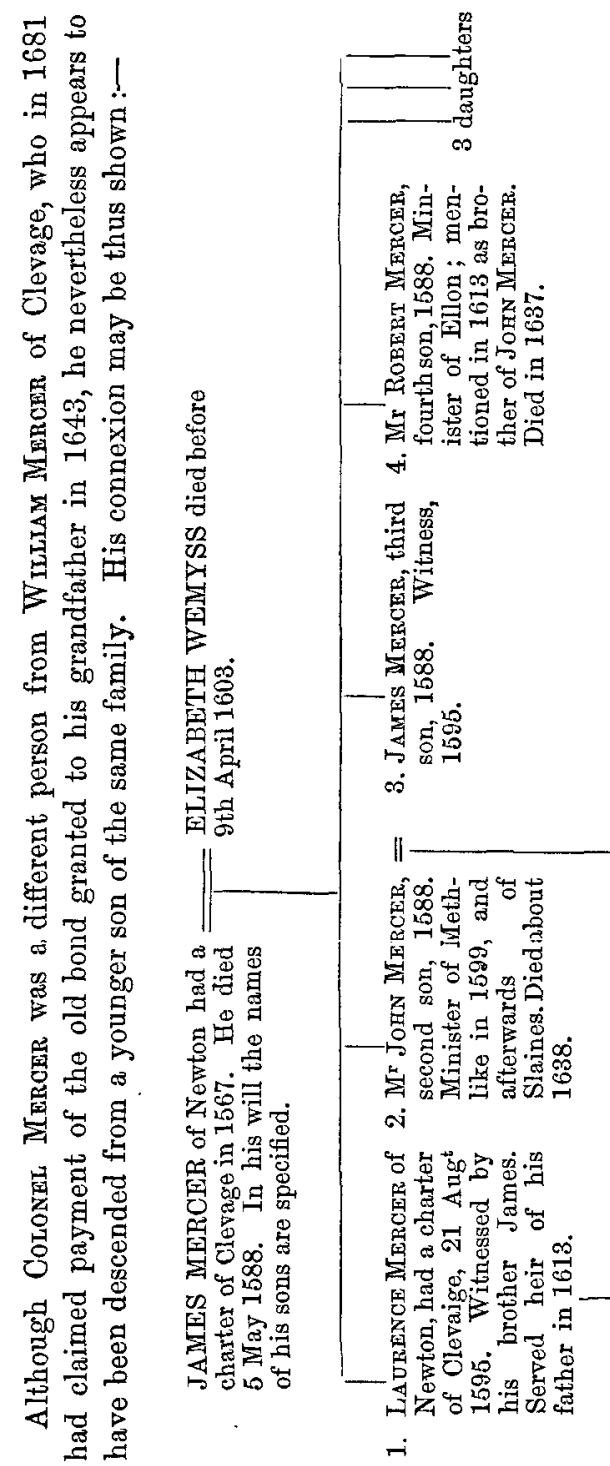

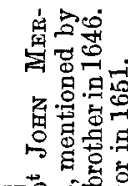

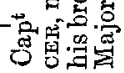

๓ं

宊

:

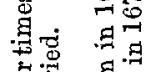

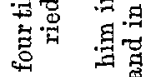

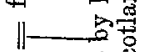

요요

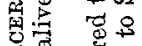

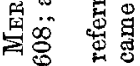

息壱鬼

3.003

구용

回

ai

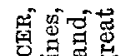

.

武氙兽

붕요의

ติ영 可总

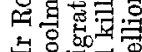

结题 党

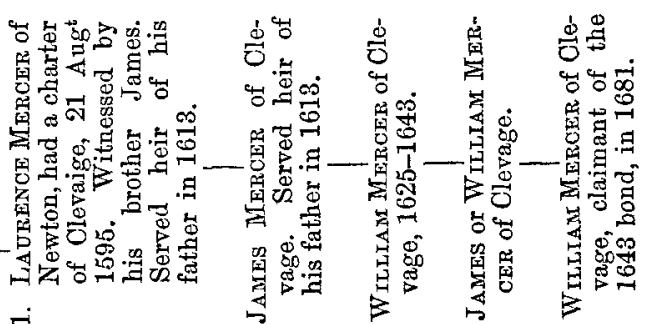

